\title{
Historical Research on Disaster Management Legislation in Iran Before Islamic Revolution
}

\author{
Jalil Arab-Kheradmand ${ }^{1}$, Shokoufeh Ahmadi ${ }^{*}$, Akram Baniasadi ${ }^{3}$, Hamidreza Khankeh ${ }^{2,4}$
}

1. Iranian Virtual Institute for Disasters and Emergencies, Ahya Neuroscience Research Center, Tehran, Iran.

2. Health in Emergency and Disaster Research Center, University of Social Welfare and Rehabilitation Sciences, Tehran, Iran.

3. Department of Health Management and Economics, School of Public Health, Tehran University of Medical Sciences, Tehran, Iran.

4. Department of Clinical Science and Education, Karolinska Institute, Stockholm, Sweden.

Citation: Arab-Kheradmand J, Ahmadi SH, Baniasadi A, Khankeh HR. Historical Research on Disaster Management Legislation in Iran: A Case Study. Health in Emergencies and Disasters Quarterly. 2016; 1(4): 209-214. https://doi.org/10.18869/nrip.hdq.1.4.209

: https://doi.org/10.18869/nrip.hdq.1.4.209

Article info:

Received: 20 Jan. 2016

Accepted: 30 May 2016

\section{Keywords:}

Disaster management, Legislation, Iran

\begin{abstract}
Various disasters are still inevitable and over the last two decades, affected lives of at least 800 million people. Iran is one of the most disaster-prone countries and about $90 \%$ of the country are at risks of earthquakes or floods. Thus, the disaster management in our country is a priority. In recent years, several protocols have been put forward to manage the emergencies and disasters. In this regard, the related laws and regulations crisis management are an integrated part of any crisis management which specifies each organization role. One of the important pitfalls in managing risk reduction approach, is the lack of proper laws and regulations and their implementation. Moreover, national guidelines and protocols provides the pathways for different areas of intervention. To solve this shortcoming, a historical review of legislation in this area is helpful. This study aims to review the legislative history of disaster management in Iran, the responsible organizations, and their strong and weak points. This study might help reduce vulnerabilities and boost coordination in crisis management.
\end{abstract}

\section{Introduction}

$\mathbf{H}$

uman history indicates that the occurrence of various events has been one of the most important concerns of the man. Most emergencies and disasters are still inevitable and by environmental and demographic changes and manipulation, communities are increasingly exposed to the new and more different events [1]. Over the last two decades, natural disasters in the world affected lives of at least 800 million people, led to the deaths of thousands, and the economic damage of more than $\$ 50$ billion. Every year more than 128000 people lose their lives due to natu- ral disasters [2] and still more are influenced by their direct and indirect consequences. Iran is one of the most disasterprone countries which is among top ten countries in this regard. In terms of natural disasters incidence, Iran ranks the fourth in Asia and sixth in the world. Actually, $90 \%$ of the country are exposed to the wide risks of earthquakes and floods [3]. In addition, Islamic Republic of Iran is the victim of man-made disasters, terrorist acts, and the eightyear defend Iran against Iraq (Iran - Iraq war 1990 -1991). Among the various components of disaster management, the rules and principles of disasters management are of special importance and an integrated disasters management

* Corresponding Author:

Shokoufe Ahmadi, PhD Candidate

Address: Health in Emergency and Disaster Research Center, University of Social Welfare and Rehabilitation Sciences, Tehran, Iran

E-mail: ahmadi.shokoufeh@gmail.com 
rules which allocates the role of each organization and leads to efficient disasters management, is essential.

In addition to unavoidable factors in emergencies and disasters, some human controllable factors affect the emergence and exacerbating the problems caused by disasters. One of the most important factors is inability to develop and promote risk reduction approach, mainly due to lack of upstream law and regulations [5]. One of the most important condition for reducing the negative effects caused by disasters is exciting proper laws and providing support for their implementation [6]. According to the World Health Organization, developing a comprehensive legal body which is based on indigenous research is the most important requirement for improving preparedness and resilience of communities. On the other hand, the lack of proper laws in the event of disasters leads to increased deaths and the government's inability to provide an effective response to disasters [7]

In addition to a comprehensive legal framework, development of national guidelines and protocols provides the necessary pathways for different areas of intervention [8]. To achieve this goal, the historical process of legal development and comprehensive evaluation of existing legislation is efficient. Actually, paying attention to historical evolution of these rules and analysis of their weaknesses, strengths, opportunities, and threats can help us to develop coherent planning and create conditions to perform better by taking historical lessons. This study seeks to portray history of changes in this area during the legislative history in Iran with a historical view on multiple rules in the field of disasters management and hopefully reveal the path to policymakers, managers, and those involved in the field of crisis management. As a result, historical review of these rules would be a guide and help to reduce vulnerabilities and organizing the necessary coordination in the field of disasters management in the future.

\section{Materials and Methods}

This study is a case study with a historical approach. Actually, a case study is a deep study of a phenomenon from different angles. In this study, the available evidence and documents have been extracted through a comprehensive review of resources, and historical decisive points were determined with a content analysis, and finally a time process of law development was extracted. Some of the key terms used for searching rules and enactments were as follows: disasters management, unprecedented disasters, earthquake, flood, drought, climate change, hazards, emergency, critical situations, passive defense, natural disaster, man-made disaster, reconstruction, rehabilitation, rescue, fire, and war victims.
Pure financial acts (except those which mentioned a management issue) approved by the cabinet to determine or allocate credit or costs associated with emergencies and disasters were not included in this article.

\section{Results}

In this study, we tried to mention the historical path of upstream law and regulations, legislation, and enactments by government since the time of the Constitutional Revolution and inauguration of the first National Consultative Assembly (July, 1906) until the Islamic (Revolution Feb,1979).

\section{Disasters management before the Islamic Revolu- tion in Iran}

\section{Joining the international conventions}

The first Iranian efforts to join international conventions returns to the International Red Cross organization during Qajar era. In December 1874, during the reign of Naser alDin Shah Qajar, Iran joined the Geneva Convention signed in 1864. In 1929, Geneva Convention held its third meeting after the end of World War I in Geneva, Switzerland, and Momtaz-Al-Salataneh, politician and ambassador of Iran in Paris was sent to the conference. During the conference, he had a very important role in explaining attitudes of Muslim societies towards International Red Cross and attained the approval of the Convention in accepting Red Lion and Sun as the official logo of the Iranian government for this society. However, for many years, no serious action was taken [9].

\section{National consultative assembly}

On August 5, 1906, Mozaffar al-Din Shah Qajar issued the decree of establishing the Constitution, 7 months after opening "House of Justice".

The first official meeting of the National Consultative Assembly was held on October 17, 1906 with inauguration speech of Mozaffar al-Din Shah Qajar. Iran's Parliament was founded on December 30, 1906.

\section{A. The first legal provisions adopted in the field of disaster managment}

About 9 months after the first Act of the National Consultative Assembly, Municipality law was approved in which the subject of disaster management was mentioned. In fact, this law is considered as the first law approved in the field of disasters management. As in the first chapter of this law, among the duties of municipality was "urban streets should be in compliance with a certain map and appropriate measures should be taken against fire and 
Table 1. Disaster Management Laws and Enactments before the Islamic Revolution in Iran.

\begin{tabular}{|c|c|c|c|}
\hline \multicolumn{4}{|c|}{ Laws and Enactments } \\
\hline $\begin{array}{l}\text { Enactment Author- } \\
\text { ity }\end{array}$ & Laws of the National Consultative Assembly & Enactments by the Government & Other Enactments \\
\hline Number & 22 & 3 & 8 \\
\hline
\end{tabular}

other natural (heavenly and earthly) disasters". Also for contracts of municipality to be considered valid, at least half of the members should be present but in emergency meetings at times of natural disasters or war, this rule will be ignored and contracts of the city council will be valid with the presence of any number of members. After enact-

Table 2. Disaster Management Enactments approved by the National Consultative Assembly before the Islamic Revolution in Iran

\begin{tabular}{|c|c|c|}
\hline Row & Enactments Approved by the National Consultative Assembly & Date \\
\hline 1 & Law of municipality & May 31, 1907 \\
\hline 2 & Establishment of states and provinces and rulers instructions act & $\begin{array}{l}\text { December 17, } \\
1907\end{array}$ \\
\hline 3 & Law of allocating 50000 Tomans (The then Iran currency) credit to stop locust plagues & $\begin{array}{l}\text { December 16, } \\
1922\end{array}$ \\
\hline 4 & $\begin{array}{l}\text { Act of accession of the Iranian government to international relief contracts and the statute of the interna- } \\
\text { tional relief union }\end{array}$ & July 5, 1932 \\
\hline 5 & Legal decision about 6-person commission election to assist and accompany victims of Gorgan city & April 11, 1942 \\
\hline 6 & Cadastral tax law and income tax & July 20, 1949 \\
\hline 7 & Law relating to obtaining one-thousandth of registered deals to help the Red Lion and Sun of Iran Society & $\begin{array}{l}\text { August 6, } \\
1952\end{array}$ \\
\hline 8 & Municipality Law & March 1, 1955 \\
\hline 9 & Law for establishment of Special Real State Agency & July 3, 1955 \\
\hline 10 & Law relating to the contract between Iran and Pakistan regarding disposal of locusts & July 18, 1955 \\
\hline 11 & Law for the establishment of Civil Defense Organization & $\begin{array}{l}\text { March 19, } \\
1957\end{array}$ \\
\hline 12 & Law for Flood Seal of Tehran and continuation of Kennedy Avenue to Hotel Hilton & $\begin{array}{l}\text { December 9, } \\
1958\end{array}$ \\
\hline 13 & $\begin{array}{c}\text { Law allowed acceptance for Membership of the Iranian Civil Defense Organization in the International Civil } \\
\text { Defense Organization }\end{array}$ & $\begin{array}{l}\text { February 15, } \\
1966\end{array}$ \\
\hline 14 & Act for prevention and fight against flood risks & June 21, 1966 \\
\hline 15 & $\begin{array}{c}\text { Bylaw of Technical Commission subject to Note } 2 \text { of Article } 1 \text { of the prevention and fight against flood risks } \\
\text { Act }\end{array}$ & April 29, 1969 \\
\hline 16 & Law amending the State Civil Defense Organization Law & $\begin{array}{l}\text { December 31, } \\
1970\end{array}$ \\
\hline 17 & $\begin{array}{c}\text { Administrative bylaw of Act amending the country Civil Defense Organization agency about its tasks and } \\
\text { organization }\end{array}$ & May 16, 1972 \\
\hline 18 & Warehouses safety regulation & $\begin{array}{l}\text { March 18, } \\
1973\end{array}$ \\
\hline 19 & Law for establishment of Relief Fund for villagers & $\begin{array}{l}\text { December 1, } \\
1974\end{array}$ \\
\hline 20 & $\begin{array}{c}\text { Law for disciplinary violations of public servants responsible for rescuing and relief support and Civil Defense } \\
\text { Organization of the country }\end{array}$ & $\begin{array}{l}\text { December 26, } \\
1974\end{array}$ \\
\hline 21 & Law of the organization for the national preparedness and mobilization of civilian people & May 13, 1975 \\
\hline 22 & The law on amendment articles 2 and 4 of law amending the law on civil defense organization & April 19, 1977 \\
\hline
\end{tabular}


Table 3. Disaster Management Enactments approved by the Cabinet before the Islamic Revolution in Iran.

\begin{tabular}{|c|c|c|c|}
\hline Row & Enactments & Date & Page \\
\hline 1 & Enactments by the government before the Islamic Revolution & December 14, 1955 & 45 \\
\hline 2 & Board regulations for assistance to the victims & February 14, 1977 & 61 \\
\hline 3 & Law of the organization for the national preparedness and mobilization of civilian people & October 5, 1977 & 63 \\
\hline
\end{tabular}

ment of the law of municipality, the first municipality was founded in Tabriz and consequently firefighting station of Tabriz opened in 1917 and all tasks regarding to deal with unexpected events were entrusted to this organization [10].

\section{B. Establishing States and Provinces Act and the Rul- ers Instructions}

The second important law which was passed at this time was Establishing States and Provinces Act and the Rulers instructions in which firefighters offices become responsible for celestial disasters, river flooding, communicable diseases, agricultural pests, forest fires, and storms. In addition, volunteered people for assistance in disasters were also addressed [11].

The first city in which the municipality was established

The first municipality city was established in Tabriz. Ten years after the opening of the municipality, Qasim Khan Vali, founded Fire Department of Tabriz in April, 1917 and specified tasks for this department such as investigating unprecedented disasters ranging from floods and earthquakes to debris, falls, etc. He also tried to procure tools and equipment required for dealing with these disasters and put them at disposal of officers and employees of fire administration [10]

\section{Society of Red Lion and Sun of Iran}

Until 1923, there was no organization or national institution for organized activities to manage disasters and emergencies in the country [12].

Dr. Amir Alam (1877-1961) who was a military person presented his MD thesis entitled "Sanitation in Islam" in Lyon Military Medical School, France in 1904. He investigated all damaged areas in the event of an earthquake in Shirvan and Salmas with the help of several doctors. Due to the extent of damage and its reflection in the country, he called army in to help victims and in this way, the first national assistance to help those in disaster was provided. Army relief operations was a spark for the establishment of Red Lion and Sun Society of Iran.

After Bojnoord earthquake, Dr. Amir Alam translated regulations issued by the International Red Cross and presented it to King Ahmad Qajar. According to the translated text, regulations for Red Lion and Sun of Iran Society was prepared and it was signed in March 1923 by Mohammad

Table 4. Disaster Management Enactments approved by the other organization before the Islamic Revolution in Iran.

\begin{tabular}{|c|c|c|c|c|}
\hline Row & Other Enactments Before the Islamic Revolution & Date & Enactment Authority & Page \\
\hline 1 & Constitution of the Red Lion and Sun of Iran society & March, 1923 & $\begin{array}{l}\text { Prince, Mohammad Hassan Mirza } \\
\text { Qajar }\end{array}$ & 34 \\
\hline 2 & Statute of the Red Lion and Sun of Iran society & May 16, 1948 & King Mohammad Reza Pahlavi & 39 \\
\hline 3 & $\begin{array}{l}\text { A bill to increase the share of agriculture and agricultural } \\
\text { development organization }\end{array}$ & $\begin{array}{l}\text { August 12, } \\
1952\end{array}$ & Prime Minister & 41 \\
\hline 4 & $\begin{array}{l}\text { Regulations of technical commission subject to note } 2 \text {, article } \\
1 \text { on the prevention and fight against flood risks act }\end{array}$ & $\begin{array}{l}\text { December 31, } \\
1970\end{array}$ & $\begin{array}{l}\text { Country Commission of the } \mathrm{Na}- \\
\text { tional Consultative Assembly }\end{array}$ & 51 \\
\hline 5 & $\begin{array}{l}\text { Statute of fire fighting department and safety services in } \\
\text { Tehran }\end{array}$ & May 24, 1971 & Tehran City Council & 52 \\
\hline 6 & Safety regulations of warehouses & $\begin{array}{l}\text { September 3, } \\
1973\end{array}$ & $\begin{array}{l}\text { Country Commission of the Na- } \\
\text { tional Consultative Assembly }\end{array}$ & 55 \\
\hline 7 & Red Lion and Sun of Iran society statute & $\begin{array}{l}\text { October 9, } \\
1974\end{array}$ & King Mohammad Reza Pahlavi & 56 \\
\hline 8 & Statute of fire fighting organization and safety services & $\begin{array}{l}\text { August 30, } \\
1974\end{array}$ & Tehran City Council, $103^{\text {rd }}$ session & 56 \\
\hline
\end{tabular}


Hassan Mirza Qajar, Crown Prince of Iran. This regulation had an introduction and thirteen acts that has come to pass by Ministerial delegation based on the proposal of the Interior Ministry. In the introduction, supervision of Interior Ministry on the Society was divided into two administrative-financial and technical parts. The regulation comprised acts about the Society activities, how to replace board members, how to handle bills of the Society by the Interior Ministry and the obligation of Society reports to the Ministry. According to the National Archives of Iran with document number 11038-113015 dated on August 22, 1936, regulations of implementing the supervision of the Ministry of Interior on the Society of Red Lion and Sun have been approved by the Cabinet [11].

In 1924, Society of Red Lion and Sun was recognized by the International Federation of Red Cross and Red Crescent Societies and in 1929, Red Lion and Sun Society of Iran accepted membership of International League of Red Cross.

\section{Formation of civil defense organization}

Law for establishment of Civil Defense Organization was approved on December 9, 1958, which was referred to the formation of an organization called the Civil Defense Organization affiliated to the Interior Ministry. Its duty was reported as follows: to protect life and property of citizens against air attacks and natural and unexpected disasters, reducing their effects as well as spiritual strengthening and creation of interests and mutual cooperation between people at times of abnormal and emergency situations . Actually, the most effective pre-revolutionary disasters management organization was this department that had three missions. The first mission of this organization was guidance, control, and support of the people during emergencies and natural disasters. The second mission was to help, rescue, and relief in emergencies and disasters. The third mission was reducing the vulnerabilities of the country in the face of external threats. This organization was acting under the direct supervision of the governor and Interior and War ministries were responsible for enforcement of this Act. This was the first law that has taken into consideration rather comprehensively the disasters management in both natural and man-made disasters (Air assault) [11].

On August 22, 1966, the National Consultative Assembly approved the Act of Iran Civil Defense Organization authorization in the International Civil Defense Organization [12].

Amendment of State Civil Defense Organization law was approved by the National Consultative Assembly on May 16,1972 . According to the provisions of this Act, management of war and man-made disasters was clearly the duties of this organization and also at this time the organization was separated from the Ministry of Interior and was directly put under supervision of the Prime Minister, and its responsibility was entrusted to the deputy prime minister [11].

Establishment of national preparedness and civilian mobilization (Basij) organizations

On May 13, 1957, law for establishment of organization for the National Preparedness and Mobilization of Civilian people was approved. According to article 1, organization for the national preparedness and mobilization of civilian was formed under supervision of Prime Minister in order to create maximum preparedness in departments and agencies, state-owned companies and municipalities, subsidiaries and their affiliates, other public and private sector organizations, and people to deal with emergencies and coordination between departments and agencies, municipalities, and subsidiaries as well as their affiliates. Head of this department was the Deputy Prime Minister and appointed according to the proposal of the Prime Minister and royal decree [11].

On April 18, 1977, amendment law of articles 2 and 4 of law on Civil Defense Organization was approved by the National Consultative Assembly. In accordance with the provisions of this Act, supervision of this organization was taken from the Prime Minister and was given to the Interior Ministry again [13].

\section{Laws and enactments}

Table 1 presents laws and ratifications in the field of disaster management which have been approved before the Islamic Revolution in Iran. Tables 2, 3, and 4 show the decisions of the National Consultative Assembly, cabinet, and other Organization, respectively.

\section{Conclusion}

By reviewing disasters management laws and regulations before the revolution, it seems that Iran has been one of the pioneers in passing disasters management laws. In all the times before the Islamic Revolution we had the Coordinated Management of Natural and Man-made disasters there. Although the management has been moved several times between the Prime Minister and the Interior Ministry.

\section{Acknowledgements}

The current research hasn't received any financial support. 


\section{Conflict of Interest}

The authors declared no conflict of interests.

\section{References}

[1] Kenny C. Why do people die in earthquakes? The costs, benn efits and institutions of disaster risk reduction in developing countries. The Costs, Benefits and Institutions of Disaster Risk Reduction in Developing Countries (January 1, 2009). Washington, D. C.: World Bank Policy Research Working Paper Series; 2009.

[2] Djalali A, Hosseinijenab V, Hasani A, Shirmardi K, Castrén M, Öhlén G, et al. A fundamental, national, medical disaster management plan: an education-based model. Prehospital and Disaster Medicine. 2009; 24(06):565-69. PMID: 20301078

[3] Japan International Cooperation Agency. The study on seismic microzoning of the Greater Tehran Area in the Islamic Republic of Iran. Japan: OYO Cooperation; 2000.

[4] Rosenthal U, Kouzmin A. disaster and disaster management: Toward comprehensive government decision making. Journal of Public Administration Research and Theory. 1997; 7(2):277-304. doi: 10.1093/oxfordjournals.jpart.a024349

[5] Birkmann J. Measuring vulnerability to promote disasterresilient societies: Conceptual frameworks and definitions. Measuring Vulnerability to Natural Hazards: Towards Disaster Resilient Societies. 2006; 1:9-54.

[6] United Nations Office for Disaster Risk Reduction. Hyogo framework for action 2005-2015: Building the resilience of nations and communities to disasters. Geneva: United Nations Office for Disaster Risk Reduction; 2005.

[7] World Health Organization, Center for Disease Control and Prevention. Rapid health response, assessment, and surveillance after a tsunami--Thailand, 2004-2005. Morbidity and Mortality Weekly Report. 2005; 54(3):61-64. doi: 10.1001/ jama.293.9.1052

[8] Perry RW, Lindell MK. Preparedness for emergency response: guidelines for the emergency planning process. Disasters. 2003; 27(4):336-50. doi: 10.1111/j.0361-3666.2003.00237.x

[9] Samadi Miarkolaei H, Babaei A, Samadi Miarkolaei H. [The importance of the role of Islamic Republic of Iran Red Crescent society in deal with natural disasters \& events in crisis management (Persian)]. Journal of Rescue \& Relief. 2012; 4(3):94-107.

[10] Fallah Tootkar H, Bitarafan M. [Formation and function of Baladieh association of Isfahan in the first term of National Consultative Assembly (Persian)]. Cultural History Studies. 2011; 2(7):93-120.

[11] Bani Asadi A, Arab-Kheradmand J, Khani R, Ahmadi Sh. [Iranian laws and regulations in time crisis management: List of constitutional (from August 1906 to 2015). Tehran: Sazmane Basij-e Jame'e-ye Pezeshki.
[12] Fayazi E. [History and practice "lion and Red sun society" in the era Reza Shah based on documents (Persian)]. History. 2009; 4(12):65-89.

[13] Saed N, Saed M. [Criticism of the role of Basij in the light of the Fourth Development Plan: shortcomings and solutions (Persian)]. Motaleat-e Rahbordi-ye Basij, 2005; 1(8):5-40. 